\title{
The Application of the Fuzzy Delphi Technique to the Required Aspect of Parental Involvement in the Effort to Inculcate Positive Attitude among Preschool Children
}

\author{
Nurul Khairani Ismail, Suziyani Mohamed*, Mohd Isa Hamzah \\ Fakulti Pendidikan, Universiti Kebangsaan Malaysia (UKM), Selangor, Malaysia \\ Email: *suziyani@ukm.edu.my
}

How to cite this paper: Ismail, N. K., Mohamed, S., \& Hamzah, M. I. (2019). The Application of the Fuzzy Delphi Technique to the Required Aspect of Parental Involvement in the Effort to Inculcate Positive Attitude among Preschool Children. Creative Education, 10, 2907-2921. https://doi.org/10.4236/ce.2019.1012216

Received: October 21, 2019

Accepted: November 26, 2019

Published: November 29, 2019

Copyright $\odot 2019$ by author(s) and Scientific Research Publishing Inc. This work is licensed under the Creative Commons Attribution International License (CC BY 4.0).

http://creativecommons.org/licenses/by/4.0/

c) (i) Open Access

\begin{abstract}
The aim of this article is to obtain experts' consensus on the need for parental involvement in the effort to inculcate preschool children's attitude, which covers several dimensions namely school-based involvement, home-based involvement and communication between the home and the school. The verification was done by 11 panel members or experts on the survey instrument containing items, and it was analyzed using the Fuzzy Delphi technique template. The study establishes that there is an agreement among the experts on parents' involvement in the formation of preschool children's attitude, be it in the school-based involvement, home-based involvement and communication between the home and the school. All items, totaling 24 items in the dimensions of school-based involvement, home-based involvement and communication between the home and the school, have obtained experts' consensus exceeding $75 \%$ with 22 of them obtaining the threshold reading $(d) \leq 0.2$. Next, the items involved were arranged by position based on the defuzzification value and improved with some additional items as proposed by the panel of experts.
\end{abstract}

\section{Keywords}

Expert Consensus, Parental Involvement, Fuzzy Delphi Technique, Attitude, Preschool Children

\section{Introduction}

Disruptive behaviour problems like hitting other children, screaming, frequently crying and lack of attention, are associated with delinquency and failing in 
school and it needs the attention of all relevant parties (Caspi et al., 1996). But in reality most of them prefer to wait until a circumstance gets worse before they adopt a more serious attitude in the development of children's attitude (McCormick et al., 2014). As children demonstrate the potential and learn new attitudes from home from childhood to adulthood, so parents are important individuals that play a role in trying to inculcate this attitude (Kocyigit, 2015; Loomans, 2014).

Most parents are aware that their involvement in various dimensions gives a positive impact on the formation of children's attitudes (Nokali, Bachman, \& Votruba-drzal, 2011). The diversity of dimensions of parental involvement at early schooling age is closely linked with the reduced rate of behavioural problems and the enhancement of school readiness among children (Badri et al., 2014). Although there are various studies on parental involvement at various levels (e.g., Crosnoe, 2009; Hill \& Tyson, 2009; Kuperminc, Darnell, \& Alvarez-Jimenez, 2008), it has been a need to look into the initial phase of formal education because early experiences can influence the way parents are involved in the future (Izzo et al., 1999; Badri et al., 2014). Additionally, previous studies have concentrated a great deal on parental involvement focusing more on academic achievement than students' behaviour (McCormick et al., 2014).

This study seeks to obtain the experts' consensus on the items of parental involvement done on a group of experts with regard to the study field using Fuzzy Delphi technique. Fuzzy Delphi technique or Fuzzy Delphi Method (FDM) is a technique introduced by Murray, Pipino and Gigch (1985). It is the combination between the Fuzzy set theory and the Delphi technique. This article attempts to highlight the FDM application on a study conducted by the writer involving several phases of study. However, this article only explains one phase which uses FDM as a system analyzing the study findings. Parents' involvement in this study involves three dimensions namely school-based involvement, home-based involvement and communication between the home and the school.

\section{Study Methodology}

\subsection{Data Collection Technique}

The study that has been done employs the Fuzzy Delphi technique to obtain experts' consensus on the item parental involvement based on the finding from Phase I previously. Phase I of the study is done by conducting a need analysis through an interview with the teacher on the need for parental involvement in inculcating preschool children's attitude and through the library study related to it. This writing does not discuss the previous initial findings but it only focuses on the findings from the use of the Fuzzy Delphi technique.

The study participants are 11 experts from early education lecturers, Islamic education lecturer, children's early education main coach, and Islamic education main coach. The study instrument contains 24 items distributed to the experts. The items were developed based on the findings from Phase I and II of the study that needs to be verified by the experts to reach their consensus. 
To implement the Fuzzy Delphi technique in this study, the researcher determined and arranged the items in advance through the findings of Phases I and II in a neat form and can be mastered by the experts. Afterwards, researcher decided on a group of experts who agreed to contribute their expertise in giving ideas, criticising and improving the items developed by the researcher.

When the Fuzzy Delphi study was conducted, experts interacted with the questionnaire items by identifying their level of agreement on every item, also by reducing, adding and improving the items if they think that the action is necessary. The items were tested for validity in terms of the content validity involving the process of strengthening the statements, using the language that is consistent with the language register of education and the clarity of meaning for every item through the Seven-Point Likert Scale that depicts their level of agreement. The use of the 7 Likert Scale in the Fuzzy Delphi questionnaire form to show the level of agreement of the experts on the items is deemed appropriate, because the higher the scale, the more accurate and precise the data obtained (Mohd Ridhuan et al. 2013).

The study data from the Likert Scale translated into Fuzzy number data were analysed using the Excel software. This data analysis technique is known as Fuzzy Delphi technique or Fuzzy Delphi Method (FDM). Experts' comments and suggestions are also considered to improve the existing items.

\subsection{The Data Analysis Technique of the Fuzzy Delphi Technique}

There are two important aspects in the Fuzzy Delphi technique namely the Triangular Fuzzy Number and the Defuzzification process. The data analysis process began by getting the triangular fuzzy number by arranging the values of $m_{1}, m_{2}$ dan $m_{3}$. The value of $m_{1}$ represents the minimum value, then the value $m_{2}$ represents the reasonable value whereas value $m_{3}$ represents the maximum value. Triangular Fuzzy Number is adopted to produce the Fuzzy scale (similar to the Likert scale) to translate the linguistic variable to the fuzzy number. The level of agreement for the Fuzzy scale comes in odd number.

The Likert scale data obtained was analysed using the Excel program to get a more organised tabulation. All the data were converted into the form of the triangular Fuzzy number. There are two examples of Fuzzy scales namely the five-point and the seven-point Fuzzy scales. For the purpose of this study, researcher used the latter, as shown in Table 1.

To get experts' consensus on every item, the threshold value should not be more than 0.2 . The percentage of experts' consensus needs to be more than the value of $75 \%$ whereas the defuzzication value for every item has to be more than the $\alpha$-cut value $=0.5$. In order to get the location between two fuzzy number, the formula as shown below are applied.

$$
d(\bar{m}, \bar{n})=\sqrt{\frac{1}{3}\left[\left(m_{1}-n_{1}\right)^{2}+\left(m_{2}-n_{2}\right)^{2}+\left(m_{3}-n_{3}\right)^{2}\right]}
$$

Diagram 1: Level of agreement of the Fuzzy scale 
Table 1. Seven-point Fuzzy scales.

\begin{tabular}{cc}
\hline Agreement Level Table & Fuzzy scale \\
\hline Strongly Disagree & $(0.0,0.0,0.1)$ \\
Totally disagree & $(0.0,0.1,0.3)$ \\
Disagree & $(0.1,0.3,0.5)$ \\
Not sure & $(0.3,0.5,0.7)$ \\
Agree & $(0.5,0.7,0.9)$ \\
Totally Agree & $(0.7,0.9,1.0)$ \\
Strongly Agree & $(0.9,1.0,1.0)$ \\
\hline
\end{tabular}

Resource: (Mohd. Ridhuan Mohd. Jamil et al., 2013: p. 88).

If the value $\mathrm{d} \leq 0.2$, it means that all the experts have reached a consensus towards the item. Otherwise, the second round has to be done to see if the item is needed or not (Chen, 2000; Cheng \& Lin, 2002).

Fuzzy Delphi technique also involves the process of determining the consensus of the experts whether exceeding or equals to $75 \%$ for the entire dimensions of every item. Every item is assumed to have reached the experts' consensus if the percentage of the consensus for the items is the same or is more than $75 \%$ (Chu \& Hwang, 2008; Murray \& Hammons, 1995).

The defuzzification process was also done in the data analysis process in the Fuzzy Delphi technique. It is the process of determining the position or rank of every item or determining the position of every variable or sub-variable. In this process, there are three formulas that can be applied and researcher can choose one of them as stated by Mohd. Riduan Mohd. Jamil et al. (2013) which is:

1) $\mathrm{A}=1 / 3 *\left(m_{1}+m_{2}+m_{3}\right)$ or;

2) $\mathrm{A}=1 / 4{ }^{\star}\left(m_{1}+2 m_{2}+m_{3}\right)$ or;

3) $\mathrm{A}=1 / 6^{\star}\left(m_{1}+4 m_{2}+m_{3}\right)$.

Next, the $\alpha$-cut value $=$ the median value for " 0 " and " 1 ", where $\alpha$-cut $=$ $(0+1) / 2=0.5$. If the value of A yielded is less than the $\alpha$-cut value $=0.5$, the item will be rejected because it shows the agreement of the experts in rejecting the item, but if the value of $A$ exceeds the $\alpha$-cut value $=0.5$, the item will be accepted because it shows experts' consensus to accept the item (Mohd Ridhuan et al. 2013).

The data were then tabulated to obtain the Fuzzy value $\left(n_{1}, n_{2}, n_{3}\right)$ also the average Fuzzy value $\left(m_{1}, m_{2}, m_{3}\right)$ to get the threshold value, the percentage of experts' consensus, the defuzzication value and the item ranking.

\section{Study Finding}

\subsection{Home-Based Involvement}

In this work, items for the domain "home-based involvement" given to experts are stated in Table 2.

The threshold value (d), the percentage of experts' consensus, defuzzification and the ranking of item for the above items are shown in Table 3. 
Table 2. Items for the dimension home based involvement given to expert.

\begin{tabular}{ll}
\hline Code & Statement \\
\hline PIHB 1 & Watching television with children \\
PIHB 2 & Always reading exemplary stories to children \\
PIHB 3 & Providing educational materials to form attitude such as exemplary stories (fables) and computer games \\
PIHB 4 & Spending time with children in social activities \\
PIHB 5 & Rewarding children upon the good deeds that they have done \\
PIHB 6 & Being strict on the negative deeds that children have done \\
PIHB 7 & Trying hard to become the role models for children. \\
PIHB 8 & Encouraging children to befriend other children who have good behaviour \\
PIHB 9 & Reminding children to be wary with friends who have bad behaviour \\
PIHB 10 & Reminding children that Allah always sees and observes His servants' actions and behaviour. \\
PIHB 11 & Reminding that every good and bad deed will be noted and reward/punishment will follow in the Hereafter. \\
PIHB 12 & Spending time evaluating children's daily behaviour at home. \\
PIHB 13 & Familiarising the culture of advising among children. \\
\hline
\end{tabular}

Table 3. The threshold value (d), the percentage of experts' consensus, defuzzification and the ranking of item home-based involvement dimension.

\begin{tabular}{|c|c|c|c|c|c|c|c|c|c|c|c|c|c|}
\hline \multirow{2}{*}{ Expert } & \multicolumn{13}{|c|}{ Item } \\
\hline & 1 & 2 & 3 & 4 & 5 & 6 & 7 & 8 & 9 & 10 & 11 & 12 & 13 \\
\hline 1 & 0.136 & 0.097 & 0.092 & 0.294 & 0.028 & 0.028 & 0.028 & 0.028 & 0.014 & 0.014 & 0.000 & 0.343 & 0.125 \\
\hline 2 & 0.136 & 0.056 & 0.063 & 0.098 & 0.028 & 0.028 & 0.028 & 0.028 & 0.014 & 0.014 & 0.000 & 0.049 & 0.028 \\
\hline 3 & 0.069 & 0.097 & 0.092 & 0.098 & 0.028 & 0.028 & 0.028 & 0.028 & 0.014 & 0.014 & 0.000 & 0.049 & 0.028 \\
\hline 4 & 0.136 & 0.056 & 0.063 & 0.098 & 0.028 & 0.028 & 0.028 & 0.028 & 0.014 & 0.014 & 0.000 & 0.049 & 0.028 \\
\hline 5 & 0.136 & 0.056 & 0.063 & 0.098 & 0.028 & 0.028 & 0.028 & 0.028 & 0.014 & 0.014 & 0.000 & 0.049 & 0.028 \\
\hline 6 & 0.259 & 0.097 & 0.063 & 0.098 & 0.028 & 0.028 & 0.028 & 0.028 & 0.014 & 0.014 & 0.000 & 0.049 & 0.028 \\
\hline 7 & 0.136 & 0.056 & 0.063 & 0.098 & 0.028 & 0.028 & 0.028 & 0.028 & 0.014 & 0.014 & 0.000 & 0.049 & 0.028 \\
\hline 8 & 0.136 & 0.056 & 0.063 & 0.062 & 0.028 & 0.028 & 0.028 & 0.028 & 0.014 & 0.014 & 0.000 & 0.049 & 0.028 \\
\hline 9 & 0.842 & 0.097 & 0.330 & 0.294 & 0.125 & 0.125 & 0.125 & 0.125 & 0.014 & 0.014 & 0.000 & 0.106 & 0.125 \\
\hline 10 & 0.136 & 0.056 & 0.063 & 0.098 & 0.028 & 0.028 & 0.028 & 0.028 & 0.014 & 0.014 & 0.000 & 0.049 & 0.028 \\
\hline 11 & 0.136 & 0.056 & 0.063 & 0.062 & 0.125 & 0.125 & 0.125 & 0.125 & 0.139 & 0.139 & 0.000 & 0.049 & 0.028 \\
\hline $\begin{array}{l}\text { The value of } d \\
\text { of every item }\end{array}$ & 0.205 & 0.071 & 0.092 & 0.127 & 0.045 & 0.045 & 0.045 & 0.045 & 0.025 & 0.025 & 0.000 & 0.081 & 0.045 \\
\hline $\begin{array}{l}\text { The percentage of } \\
\text { Experts' consensus } \\
\text { of every item }\end{array}$ & $91 \%$ & $100 \%$ & $91 \%$ & $100 \%$ & $100 \%$ & $100 \%$ & $100 \%$ & $100 \%$ & $100 \%$ & $100 \%$ & $100 \%$ & $91 \%$ & $100 \%$ \\
\hline $\begin{array}{l}\text { The percentage of } \\
\text { consensus of experts } \\
\text { for all items }\end{array}$ & & & & & & & & & & & & & \\
\hline $\begin{array}{l}\text { Defuzzification/item } \\
\text { score value }\end{array}$ & 0.873 & 0.930 & 0.924 & 0.900 & 0.948 & 0.948 & 0.948 & 0.948 & 0.958 & 0.958 & 0.967 & 0.933 & 0.948 \\
\hline Item ranking & 13 & 10 & 11 & 12 & 4 & 4 & 4 & 4 & 2 & 2 & 1 & 9 & 4 \\
\hline
\end{tabular}

${ }^{*}$ Method 1: A*Method 1: All items have an average threshold value (d) more than 0.2 except for item PIHB $1 .{ }^{* *}$ Method 2: The percentage of experts' consensus shows that all the items have exceeded the value of $75 \% .{ }^{* *}$ Method 3 : All the defuzzification values for every item exceed the $\alpha$-cut value $=0.5$. 
Based on Table 3 for the aspect home-based involvement, all items that have passed the threshold value of $(\mathrm{d})=0.2$ except for item PIHB1. According to Cheng and Lin (2002), if the average value and experts' consensus on the items are less than the threshold value of 0.2 , the items have obtained experts' consensus. Although the finding shows that item PIHB 1's threshold value is more than $(d)=0.2$, the percentage of experts' consensus shows that the item is more than the value of $75 \%$ which is $82 \%$. Thus, the items involved are accepted as the items of this dimension. Meanwhile, for all other items in this dimension, they have an average threshold value of (d) more than 0.2 , and the percentage of expert consensus more than $75 \%$ and with the $\alpha$-cut value more than 0.5 . Conclusively, all the items for this dimension obtained expert consensus in forming the attitude of preschool children. The items arranged by priority are as shown below in Table 4.

Based on the order of priorities of the items in Table 4, items that are characteristically internal in the form of an individual's faith in influencing children's behaviour through the manner of reminding occupied the first and second place from the order of priority, followed by items from the environmental influence, namely peer influence and other items.

\subsection{School-Based Involvement}

In this study, the items for the dimension "school-based involvement" given to experts are as stated in Table 5.

Table 4. Priority of items for home based dimension.

\begin{tabular}{|c|c|c|}
\hline Order of priority & Item & No Item \\
\hline 1 & $\begin{array}{l}\text { Reminding them that every good or bad deed will be noted and } \\
\text { will be rewarded or punished accordingly in the Hereafter }\end{array}$ & PIHB 11 \\
\hline 2 & $\begin{array}{l}\text { Reminding the children that Allah is always looking out and } \\
\text { observing His servants' behaviour }\end{array}$ & PIHB 10 \\
\hline 2 & Reminding children to be wary of friends who have a bad attitude & PIHB 9 \\
\hline 4 & Encouraging children to befriend people with good attitude & PIHB 8 \\
\hline 4 & Trying hard to be the role model for children & PIHB 7 \\
\hline 4 & $\begin{array}{l}\text { Showing assertiveness on negative attitude demonstrated by } \\
\text { children }\end{array}$ & PIHB 6 \\
\hline 4 & $\begin{array}{l}\text { Rewarding the children on the noble attitude that they have } \\
\text { demonstrated }\end{array}$ & PIHB 5 \\
\hline 4 & Familiarising the culture of advising among children & PIHB 13 \\
\hline 9 & Spending time evaluating children's daily behaviour at home & PIHB 12 \\
\hline 10 & Always reading exemplary stories to children & PIHB 2 \\
\hline 11 & $\begin{array}{l}\text { Preparing educational materials for attitude development, such as } \\
\text { fables and computer games. }\end{array}$ & PIHB 3 \\
\hline 12 & Spending time with children in societal activities & PIHB 4 \\
\hline 13 & Watching television with children & PIHB 1 \\
\hline
\end{tabular}


Table 5. Items for the dimension school-based involvement given to the experts.

\begin{tabular}{ll}
\hline Item & \\
\hline PISH 1 & $\begin{array}{l}\text { Giving ideas and suggestions to improve the school } \\
\text { Taking part in the decision-making in school activities that give an impact to } \\
\text { children's attitude }\end{array}$ \\
PISH 3 & $\begin{array}{l}\text { Contributing ideas in school meetings } \\
\text { PISH } 4\end{array}$ \\
\hline
\end{tabular}

The threshold value (d), the percentage of experts' consensus, defuzzification and the ranking item for the items above are shown in Table 6.

Based on Table 6 for the dimension school-based involvement, all items have the threshold value (d) less than 0.2 except for item PISH 2. According to Cheng and Lin (2002), if the average value and experts' evaluation are less than the threshold value 0.2 , the item has obtained experts' consensus. Although the finding shows that item PISH 2 of the threshold value is more than $(d)=0.2$, the percentage of consensus given by experts shows their uniformity on the item which is more than $75 \%$ or $82 \%$. Thus, the item is accepted. All other items obtain the percentage of agreement of more than $75 \%$ and the defuzzification value for every item also exceeds the $\alpha$-cut value $=0.5$. This demonstrates that the items are accepted as items and they have acquired the consensus in the formation of the preschool children's attitude. The items arranged by priority are shown in Table 7.

Based on the items' priority in Table 7, the items about contribution of ideas and physical involvement are placed first from the list of priorities, followed by other items in the list of school-based involvement items.

\subsection{Communication between Home and School}

In this study, the items for the dimension communication between home and school given to the experts are stated below, in Table 8 .

The threshold value (d), the percentage of experts' consensus, defuzzification and the item ranking for the above items are shown in Table 9.

Based on Table 9 for the aspect "communication between home and school", all the items have a threshold value (d) less than 0.2 , and other than that, all the items obtain the percentage of experts' agreement exceeding the value of $75 \%$ and the defuzzification value for every item exceeding the $\alpha$-cut value $=0.5$. This reveals that these items are accepted as items and they are generally agreed to be part of the formation of attitude of the preschool children. The items arranged by priority are as illustrated in Table 10 .

Based on Table 10, the item "discussing with the teacher about the difficulties that the children face" is on the first rank, followed by regularly reading the report that the teacher provides' and also other items in the dimension of the communication between home and school. 
Table 6. The threshold value (d), the percentage of experts' consensus, defuzzification and the ranking item for school-based involvement.

\begin{tabular}{|c|c|c|c|c|}
\hline \multirow{2}{*}{ Expert } & \multicolumn{4}{|c|}{ Item } \\
\hline & 1 & 2 & 3 & 7 \\
\hline 1 & 0.111 & 0.468 & 0.125 & 0.125 \\
\hline 2 & 0.042 & 1.046 & 0.028 & 0.028 \\
\hline 3 & 0.042 & 0.210 & 0.028 & 0.028 \\
\hline 4 & 0.042 & 0.210 & 0.028 & 0.028 \\
\hline 5 & 0.042 & 0.210 & 0.028 & 0.028 \\
\hline 6 & 0.111 & 0.106 & 0.028 & 0.028 \\
\hline 7 & 0.042 & 0.210 & 0.028 & 0.028 \\
\hline 8 & 0.042 & 0.106 & 0.028 & 0.028 \\
\hline 9 & 0.111 & 0.106 & 0.125 & 0.028 \\
\hline 10 & 0.042 & 0.210 & 0.028 & 0.028 \\
\hline 11 & 0.042 & 0.210 & 0.028 & 0.125 \\
\hline The value of $d$ for every item & 0.061 & 0.281 & 0.045 & 0.045 \\
\hline $\begin{array}{l}\text { The percentage of experts } \\
\text { consensus based on every item }\end{array}$ & $100 \%$ & $82 \%$ & $100 \%$ & $100 \%$ \\
\hline $\begin{array}{l}\text { The percentage of experts' } \\
\text { consensus for the whole items }\end{array}$ & & $95 \%$ & & \\
\hline $\begin{array}{l}\text { The Defuzzification } \\
\text { Value/Item Score Value }\end{array}$ & 0.939 & 0.821 & 0.948 & 0.948 \\
\hline Item Ranking & 2 & 3 & 1 & 1 \\
\hline
\end{tabular}

${ }^{*}$ Method 1: All items have an average threshold value (d) less than 0.2 except for PISH 2. ${ }^{* *}$ Method 2: The percentage of experts' consensus shows that all items are more than the value of $75 \%$. ${ }^{* *}$ Method 3: All the defuzzification values for every item exceed the $\alpha$-cut value $=0.5$.

Table 7. Priority of items for school-based involvement dimension.

\begin{tabular}{lll}
\hline Items' order of priority & Item & No \\
\hline 1 & Contributing ideas in school meetings & PISH 3 \\
1 & Volunteering in school activities & PISH 4 \\
3 & $\begin{array}{l}\text { Giving ideas and suggestions to improve children's school } \\
\text { Making decisions in school activities that give an impact to the }\end{array}$ & PISH 1 \\
4 & PISH 2 \\
\hline
\end{tabular}

Table 8. Items for dimension communication between home and school given to experts.

\begin{tabular}{|c|c|}
\hline \multicolumn{2}{|l|}{ Item } \\
\hline PISB 1 & Discussing with teachers about children's routine at home or at school \\
\hline PISB 2 & Discussing with teachers about the difficulty faced by children at school \\
\hline PISB 3 & Discussing with teach about children's development at home or at school. \\
\hline PISB 4 & Reading the memo or report given by the teacher \\
\hline PISB 5 & $\begin{array}{l}\text { Giving the supposed response to the teacher especially involving children's attitude } \\
\text { problem }\end{array}$ \\
\hline PISB 6 & Getting to know children's socialization with other children at school \\
\hline PISB 7 & Asking teacher to politely criticise children's behaviour \\
\hline
\end{tabular}


Table 9. The threshold value (d), the percentage of experts' consensus, defuzzification and the ranking item for communication between home and school.

\begin{tabular}{|c|c|c|c|c|c|c|c|}
\hline \multirow{2}{*}{ Expert } & \multicolumn{7}{|c|}{ Item } \\
\hline & 1 & 2 & 3 & 4 & 5 & 6 & 7 \\
\hline 1 & 0.132 & 0.028 & 0.071 & 0.125 & 0.111 & 0.078 & 0.605 \\
\hline 2 & 0.132 & 0.028 & 0.071 & 0.028 & 0.042 & 0.076 & 0.074 \\
\hline 3 & 0.547 & 0.028 & 0.071 & 0.028 & 0.042 & 0.076 & 0.074 \\
\hline 4 & 0.132 & 0.028 & 0.071 & 0.028 & 0.042 & 0.076 & 0.074 \\
\hline 5 & 0.132 & 0.028 & 0.071 & 0.028 & 0.042 & 0.076 & 0.074 \\
\hline 6 & 0.132 & 0.028 & 0.071 & 0.028 & 0.042 & 0.076 & 0.074 \\
\hline 7 & 0.132 & 0.028 & 0.071 & 0.028 & 0.042 & 0.076 & 0.074 \\
\hline 8 & 0.111 & 0.125 & 0.320 & 0.028 & 0.042 & 0.317 & 0.074 \\
\hline 9 & 0.111 & 0.125 & 0.111 & 0.125 & 0.111 & 0.078 & 0.091 \\
\hline 10 & 0.132 & 0.028 & 0.071 & 0.028 & 0.042 & 0.076 & 0.074 \\
\hline 11 & 0.132 & 0.028 & 0.071 & 0.028 & 0.111 & 0.078 & 0.074 \\
\hline $\begin{array}{l}\text { The value of } \\
d \text { for every item }\end{array}$ & 0.193 & 0.045 & 0.117 & 0.045 & 0.061 & 0.099 & 0.124 \\
\hline $\begin{array}{l}\text { The percentage of } \\
\text { Experts' consensus } \\
\text { based on every item }\end{array}$ & $91 \%$ & $100 \%$ & $91 \%$ & $100 \%$ & $100 \%$ & $91 \%$ & $91 \%$ \\
\hline $\begin{array}{l}\text { The percentage of } \\
\text { experts' consensus } \\
\text { for the whole items }\end{array}$ & & & & & & & \\
\hline $\begin{array}{l}\text { The Defuzzification } \\
\text { Value/Item Score Value }\end{array}$ & 0.876 & 0.948 & 0.918 & 0.948 & 0.939 & 0.915 & 0.915 \\
\hline Item Ranking & 7 & 1 & 4 & 1 & 3 & 5 & 5 \\
\hline
\end{tabular}

${ }^{*}$ Method 1: All items have an average threshold value (d) less than 0.2. ${ }^{*}$ Method 2: The percentage of experts' consensus shows that all items are more than the value of $75 \% .{ }^{* *}$ Method 3: All the defuzzification values for every item exceed the $\alpha$-cut value $=0.5$.

Table10. Priority of items for communication between home and school dimension.

\begin{tabular}{lll}
\hline Item's order of priority & Item & No \\
\hline 1 & $\begin{array}{l}\text { Discussing with teacher about the difficulty faced by } \\
\text { children at home or at school }\end{array}$ & PISB 2 \\
1 & $\begin{array}{l}\text { Reading the memo or report given by the teacher } \\
\text { Giving the supposed response to the teacher especially } \\
\text { involving attitude problem }\end{array}$ & PISB 4 \\
3 & $\begin{array}{l}\text { Discussing with the teacher about the development of } \\
\text { children's attitude at home or at school }\end{array}$ & PISB 3 \\
4 & $\begin{array}{l}\text { Knowing about their children's socialization with other } \\
\text { children at school }\end{array}$ & PISB 6 \\
5 & $\begin{array}{l}\text { Asking teacher to politely criticise children's behaviour } \\
\text { Discussing with the teacher about their children's daily } \\
\text { routine at home or at school }\end{array}$ & PISB 7 \\
\hline 7
\end{tabular}




\section{Discussion}

In conducting the analysis using the Fuzzy Delphi technique, researcher also takes into account all the comments and suggestions put forth by experts for improvement. After the items were arranged by priority, the sentences were further improved once more, and researcher had added some other items suggested by the experts (solidified items). Table 11 shows the need for the aspect "parental involvement in the formation of children's attitude" according to the dimension.

Table 11. Summary of final items in parental involvement dimension.

The dimension of Parental involvement

1) Home-based involvement

a) Reminding that every good and bad deed will be noted and reward or punishment will be imposed in the Hereafter.

b) Reminding children that Allah always sees and observes His servants' actions.

c) Reminding children to be careful with friends who have bad attitude.

d) Encouraging children to befriend anyone with good attitude

e) Trying hard to be a good role model to children

f) Being strict on any negative attitude shown by children

g) Giving rewards on the noble attitude shown by children

h) Familiarising the culture of advising among children

i) Spending time evaluating children's daily behaviour at home

j) Always reading exemplary stories to children

k) Preparing educational materials for the development of attitude, such as exemplary stories and computer games

1) Spending time with the children in social activities

m) Watching television with the children

n) Bringing children to the mosque and mingling with the community

2) School-based involvement

a) Contributing ideas in school meetings

b) Volunteering in school activities

c) Giving ideas and suggestions to improve children's school

d) Making decisions in school activities that give an impact to the children

3) Communication between home and school

a) Discussing with teacher about the difficulty faced by children at home or at school

b) Reading the memo or report given by the teacher

c) Giving the supposed response to the teacher especially involving attitude problem

d) Discussing with the teacher about the development of children's attitude at home or at school

e) Knowing about their children's socialization with other children at school

f) Asking teacher to politely criticise children's behaviour

g) Discussing with the teacher about their children's daily routine at home or at school 
Fundamentally, preschool teachers assume that it is the responsibility of the parents to shape and discipline their children's attitude so that they can demonstrate positive behaviour at school (Makgopa \& Mokhele, 2013). Therefore, early intervention in the form of preventive action is crucial to assist the development and prevent from any behaviour and social problems to surface among the school children today (Powell et al., 2011). Thus, this study is done to identify the dimensions and items deemed the most important in the aspect of parental involvement that can be absorbed by children when they are at school.

This study finds that the dimension home-based involvement as defined by Fantuzzo et al. (2004) refers to parents' attitude and approach encompassing the provision of a conducive learning environment for the development and learning of children at home at the top rank from all three dimensions, by obtaining $98 \%$ of expert agreement, followed by the dimension "school-based involvement" and the next is "communication between the home and school" at the second place with the percentage of agreement $95 \%$. The study finding is consistent with the study carried out by Fantuzzo et al. (2004) stating that home-based involvement has the strongest association with children's behavioural development.

For the dimension of home-based involvement, advice and reminders items rank the highest in the item priority. The first item is an item of repetitive act as a consequence of behavior based on the child's own belief. Reminding that every action, good or bad, will be noted will be rewarded or punished accordingly in the Hereafter is related to the concept of self-evaluation which is assessing or analysing every action done, realising mistakes and correcting them and not repeating them in the future (Makhsin et al., 2019). Other than that, the item "Reminding the children that Allah always sees and observes His servants" actions is the concept of muraqabah' is at the second rank in the list of the items of priority. Muraqabah means one's capacity to control his or her consciousness that one is always observed by Allah and he or she is trying the best to surrender to Him and steer clear of everything that He forbids (Makhsin et al., 2019). The muraqabah process leans on the loyalty to Allah which is key to one's faith (Amina Noor, 2008). According to Lutpi Ibrahim (1983) muraqabah is divided into three which is staying loyal to the commands of Allah, steering clear from everything He forbids and being careful in every action.

Both the concepts are closely related to divinity by believing in the attributes of Allah as the most judgement and just (Mohd Farid, 2015). Other than that, the basis of eschatology also gives a strong justification on the value of attitude as put forth by the religion. With the belief that every action is observed by Allah and people shall be punished or rewarded, the effect on children's behaviour will emerge on their actions (Mohd Farid, 2015).

Children need to be reminded regularly for example when asking a student to pray, it is not sufficient to ask only with one instruction but it must be repeated. This repetition approach has also been acknowledged by well-renowned scholars 
(Ibn Khaldun, 2009). Other than that, according to (Norsaleha, Abd Halim, \& Salleh Amat, 2012) the impact from repeating something will leave a long-lasting influence in children. The moral teaching approach has to be diversified, not bound by a certain method, interesting and engaging based on minimum level of capability in retaining their concentration. Thus, teachers need to formulate full trust from the students through an effective teaching approach so that it is able to create an effective implementation of teaching practice (Zuraidah, 2013).

The new item proposed by experts would be related to the role of the parents especially fathers in steering the children and familiarising their children with the mosques. This is crucial because the inculcation of moral and good deeds will be more effective within the scope of this structure. This is because the children will naturally imitate the adults, as they can acquire both good and bad deeds from others (Zakaria Stapa, Ahmad Munawar Ismail, \& Yusuf 2012). This is consistent with Bandura's Social Cognitive Theory (1977) stating that children have the tendency to imitate what they see around them, so children will absorb and imitate a lot of positive values they observe in the mosque, for instance repeating the adzan will give a positive impact to children with religious inclination. Through mosque activities, for example, praying, children will be accustomed to the values within this act of worship, such as being disciplined, being punctual, polite, patient, obedient and so on.

Imam al-Ghazali also stressed on the factor of social learning, which is getting to know good, moral people as one of the three methods that form one's noble attitude (Muhamad Abul Quasem (1975). As most of the children's behaviour follows that or what is required by the parents and society, on the other hand, deviant behaviour stems from improper upbringing and socialisation process. Due to this, parents need to motivate their children to befriend people who are used to the religious environment, such as the mosque because peers are also identified as an agent of positive behavioural development (Zakaria, Ahmad Munawar Ismail, \& Yusuf, 2012).

Friends from a good environment will influence the behaviour and will instill positive values (Zakaria, Ahmad Munawar Ismail, \& Yusuf, 2012). Parents need to give their attention to their children's friendship aspect because peer influence has a direct correlation with children's behaviour, whereby when they start to go to school or when they can overcome parental influence on children (Blazevic, 2016). Thus, preventing children from bad peers is by introducing them to friends from a good environment such as those found in mosques (Zakaria, Ahmad Munawar Ismai, \& Yusuf 2012).

Next, the school-based involvement as defined by Fantuzzo et al. (2004) refers to parents' attitude and activities with their children at school, such as being volunteers in school activities, joining school trips, and so on. Close cooperation between parents and teachers in children's early education will instil high levels of trust and security within the children and this will determine their success in their social and academic developments (Mahmood, 2013; Reid et al., 2007; 
Semke et al., 2010).

The social cognitive theory also states that children will imitate parents' behaviour. By giving cooperation and spending time in activities at school, automatically parenst are also encouraging their children to do the same at school (McCormick et al., 2014). The social cognitive theory also helps give a deeper understanding on the relationship between Scholl-based involvement and behavioral problems (Bandura, 1977). When children observe that parents respect their teachers and are willing to spend time for school activities, they will understand that a school is a place where they demonstrate good behaviour (Bandura, 1988; Grolnick \& Slowiaczek, 1994). Parents who can spend time in school activities have the tendency to form good relationships with the teachers. Next, teachers will also regard children of this type of parents as non-problematic children (McDermott \& Rothenberg, 2000).

Finally, the dimension of parents' communication with the school as raised by Fantuzzo et al. (2004) lies in how parents communicate with the school with regard to children's development such as discussing with the teacher on the difficulties and the children's achievement, also discussing ways of encouraging children to learn at home.

The communication between parents and the school is fundamentally aiming to find the best strategy to help children in their development (Makgopa \& Mokhele, 2013). When parents and teachers frequently communicate with one another constructively, parents begin to have a clearer picture on the teacher's expectation towards their children at school, and they will be more inclined to learn from the teachers on what they need to do at home to help boost their children's development (Makgopa \& Mokhele, 2013; Izzo et al., 1999 Mahmood, 2013). Thus, parents, teachers, and the administration must work together and create an effective communication in the effort to achieve a maximum level of parental involvement in school (Kocyigita, 2015).

The gist of the home-school communication rests on the discussion between the parents and the teachers in several phases (Badri et al., 2014). The more frequent the discussion between parents and teachers, the higher the sense of trust and responsibility among them (Cankar et al., 2012). According to the study Kocyigita (2015), teachers and parents prefer to meet individually because it is more effective and more personal (Kocyigita, 2015). Meanwhile, the common way of communication between the parents and teachers is the parent-teacher meetings (Cankar et al., 2012).

\section{Conclusion}

In facing the multitude of global challenges today, most children have fallen witness and victim to a lot of social ills surrounding them from various angles from their home environment, neighbors even the school where they go every day to learn. Thus, parents as the first individuals that influence their lives should be the main protectors by giving them the best kind of education at an 
early age. Based on the finding and discussion of the study, clearly it shows that parental involvement needs to begin at home as they expose their young to basic moral values and having their integrity formed by religious basis at home. Next, the communication between the parents and teachers is also essential, so that children's positive attitude continues to be nurtured at school from home. Other than that, parents can also find the time to engage in their children's school activities.

\section{Acknowledgements}

This researcher would like to acknowledge the Faculty of Education, National University of Malaysia for the financial funding of this research through Research Grant PP-FPEND-2019.

\section{Conflicts of Interest}

The authors declare no conflicts of interest regarding the publication of this paper.

\section{References}

Badri, M., Al Qubaisi, A., Al Rashedi, A., \& Yang, G. (2014). The Causal Relationship between Parental Involvement and Children's Behavioural Adjustment to KG-1 Schooling. International Journal of Child Care and Education Policy, 8, 3. https://doi.org/10.1007/s40723-014-0003-6

Bandura, A. (1977). Social Learning Theory. Upper Saddle River, NJ: Prentice Hall.

Blazevic, I. (2016). Family, Peer and School Influence on Children's Social Development. World Journal of Education, 6, 42-49. https://doi.org/10.5430/wje.v6n2p42

Cankar, F., Deutsch, T., \& Syntonic, S. (2012). Approaches to Building Teacher-Parent Cooperation. CEPS Journal, 2, 35-55.

Caspi, A., Moffitt, T. E., Newman, D. L., \& Silva, P. A. (1996). Behavioral Observations at Age Three Years Predict Adult Psychiatric Disorders: Longitudinal Evidence from a Birth Cohort. Archives of General Psychiatry, 53, 1033-1039. https://doi.org/10.1001/archpsyc.1996.01830110071009

Chen, C. T. (2000). Extensions of the TOPSIS for Group Decision-Making under Fuzzy Environment. Fuzzy Sets and Systems, 114, 1-9. https://doi.org/10.1016/S0165-0114(97)00377-1

Cheng, C. H., \& Lin, Y. (2002). Evaluating the Best Main Battle Tank Using Fuzzy Decision Theory with Linguistic Criteria Evaluation. European Journal of Operational Research, 142, 74-86. https://doi.org/10.1016/S0377-2217(01)00280-6

Chu, H. C., \& Hwang, G. J. (2008). A Delphi-Based Approach to Developing Expert Systems with the Cooperation of Multiple Experts. Expert Systems with Applications, 34, 26-40. https://doi.org/10.1016/j.eswa.2007.05.034

El Nokali, N. E., Bachman, H. J., \& Votruba-Drzal, E. (2011). Parent Involvement and Children's Academic and Social Development in Elementary School. Child Development, 81, 988-1005. https://doi.org/10.1111/j.1467-8624.2010.01447.x

Fantuzzo, J., McWayne, C., Perry, M. A., \& Childs, S. (2004). Multiple Dimensions of Family Involvement and Their Relations to Behavioral and Learning Competencies for Urban, Low-Income Children. School Psychology Review, 33, 467-480. 
Grolnick, W. S., \& Slowiaczek, M. L. (1994). Parents' Involvement in Children's Schooling: A Multidimensional Conceptualization and Motivational Model. Child Development, 64, 237-252. https://doi.org/10.2307/1131378

Ibn, K. (2009). Muqaddimah Ibn Khaldun. Kuala Lumpur: Dewan Bahasa dan Pustaka.

Izzo, C. V., Weissberg, R. P., Kasprow, W. J., \& Fendrich, M. (1999). A Longitudinal Assessment of Teacher Perceptions of Parent Involvement in Children's Education and School Performance. American Journal of Community Psychology, 27, 817-839. https://doi.org/10.1023/A:1022262625984

Kocyigita, S. (2015). Family Involvement in Preschool Education: Rationale, Problems and Solutions for the Participants. Educational Sciences: Theory \& Practice, 15, 1-17. https://doi.org/10.12738/estp.2015.1.2474

Mahmood, S. (2013). First-Year Preschool and Kindergarten Teachers: Challenges of Working with Parents. School Community Journal, 23, 55-86.

Makgopa, M., \& Mokhele, M. (2013). Teachers' Perceptions on Parental Involvement: A Case Study of Two South African Schools. Journal of Educational and Social Research, 3, 219-226. https://doi.org/10.5901/jesr.2013.v3n3p219

Makhsin, M., Noor Farihah, M. N., Norhasimah, I., Abdul Manaf, B., Amirul, \& Fahmi, M. S. (2019). Journal of Self-Hisbah Reflection: Islamic Innovation and Creativity in Increasing Adolescent Religiosity and Resilience. International Journal of Innovative Technology and Exploring Engineering, 8, 61-66.

McCormick, M. P., Cappella, E., O’Connor, E. E., \& McClowry, S. G. (2014). Parent Involvement, Emotional Support, and Behavior Problems: An Ecological Approach. The Elementary School Journal, 114, 277-300. https://doi.org/10.1086/673200

McDermott, P., \& Rothenberg, J. (2000). Why Urban Parents Resist Involvement in Their Children's Elementary Education. Qualitative Report.

Mohd Farid, M. S. (2015). Akidah dan Pemikiran Islam: Isu dan Cabaran. Kuala Lumpur: Institut Terjemahan \& Buku Malaysia Berhad.

Murray, J. W., \& Hammons, J. O. (1995). Delphi: A Versatile Methodology for Conducting Qualitative Research. The Review of Higher Education, 18, 423.

https://doi.org/10.1353/rhe.1995.0008

Murray, T. J., Pipino, L. L., \& Gigch, J. P. (1985). A Pilot Study of Fuzzy Set Modification of Delphi. Human System Management, 5, 76-80.

Norsaleha, M. S., Abd Halim, T., \& Salleh, A. (2012). Sumbangan Penghayatan Akidah terhadap Ketenangan Hati Remaja. Bangi: Kolej Universiti Islam Selangor (KUIS).

Powell, R. B., Stern, M. J., Krohn, B. D., \& Ardoin, N. (2011). Development and Validation of Scales to Measure Environmental Responsibility, Character Development, and Attitudes toward School. Environmental Education Research, 17, 91-111. https://doi.org/10.1080/13504621003692891

Zakaria, S., Ahmad Munawar, I., \& Noranizah, Y. (2012). Faktor Persekitaran Sosial Dan Hubungannya Dengan Pembentuka Jati Diri. Jurnal Hadhari Special Edition, 155-172. (In Malay) http://journalarticle.ukm.my/6104/1/JD005862 155-172.pdf

Zuraidah, R. (2013). Kesediaan, amalan dan strategi pengajaran pendidikan Islam Kurikulum Standard Sekolah Rendah Tahun Satu (KSSR). Johor Bharu: Universiti Teknologi Malaysia. (In Malay) 